\title{
PENENTUAN LOKASI AGROINDUSTRI KOPRA DI KABUPATEN MENTAWAI DENGAN SIMULASI SISTEM DINAMIK
}

\section{LOCATION DETERMINATION OF COPRA AGROINDUSTRY IN MENTAWAI REGENCY WITH DYNAMIC SYSTEM SIMULATION}

\author{
Irna Ekawati ${ }^{1 *}$ dan Lisa Nesti ${ }^{2}$ \\ ${ }^{1)}$ Program Studi Teknik Industri Agro, Politeknik ATI Padang \\ Jl. Bungo Pasang Tabing, Padang, 25171, Indonesia \\ Email: irna_e@yahoo.com \\ ${ }^{2)}$ Program Studi Manajemen Logistik Industri Agro, Politeknik ATI Padang \\ Makalah: Diterima 12 Desember 2019; Diperbaiki 25 Maret 2019; Disetujui 10 April 2019
}

\begin{abstract}
Mentawai Islands Regency is an area in West Sumatra with its main commodity of copra. Copra produced by farmers is sold to several collectors and copra is carried outside the Mentawai for further processing by other parties. This research recommends the government to establish a copra-based agroindustry unit and bring greater added value to the Mentawai people. For this purpose, the establishment of an agroindustry consisting of copra processing plants and a major copra warehouse was proposed. This main warehouse supplyis derived from warehouses that exist on every major island in the Mentawai Islands regency. Copra produced by farmers will be directly purchased and stored in copra warehouses on each island and then sent to the main warehouse and then subsequentlyprocessed at the copra processing plant. The proposal to determine the location of the agro-industry was decided by considering the logistical costs incurred for the delivery of raw materials to the main warehouse along the copra supply chain flow which included the cost of savings and shipping costs. Location selection was carried out with a dynamic system approach due complex inter-island supply systems with copra supply values depend on the time function. Dynamic system simulation was carried out with three scenarios of agroindustry locations, namely Siberut, South Sipora, and Sikakap Island. Simulation results showed that the establishment of the main factory and warehouse was established on Sipora Island because it generates the lowest total logistics costs.
\end{abstract}

Keywords: location determination, copra, mentawai, simulation, logistic cost.

\section{ABSTRAK}

Kabupaten Kepulauan Mentawai merupakan daerah di Sumatera Barat dengan komoditas utama kopra. Selama ini kopra yang dihasilkan petani dijual ke beberapa tingkatan pengumpul dan kopra dibawa ke luar Mentawai untuk diolah selanjutnya oleh pihak lain. Penelitian ini merekomendasikan pemerintah setempat untuk mendirikan suatu unit agroindustri yang berbasis kopra sehingga mendatangkan nilai tambah yang lebih besar bagi masyarakat Mentawai. Untuk itu diusulkan pendirian sebuah agroindustri yang terdiri dari pabrik pengolahan kopra dan sebuah gudang utama kopra. Pasokan gudang utama ini berasal dari gudang yang ada pada setiap pulau besar di Kabupaten Kepulauan Mentawai. Kopra yang dihasilkan petani akan langsung dibeli dan disimpan dalam gudang kopra di setiap pulau untuk selanjutnya dikirim ke gudang utama dan selanjutnya diolah di pabrik pengolahan kopra. Usulan penentuan lokasi agroindustri diputuskan dengan mempertimbangkan biaya logistik yang dikeluarkan untuk pengiriman bahan baku ke gudang utama di sepanjang airan rantai pasok kopra yang meliputi biaya simpan dan biaya pengiriman. Pemilihan lokasi dilakukan dengan pendekatan sistem dinamik karena sistem rantai pasok antar pulau yang kompleks serta nilai persedian kopra yang bergantung dengan fungsi waktu. Simulasi sistem dinamik dilakukan dengan 3 (tiga) skenario lokasi agroindustri yaitu Siberut, Sipora Selatan dan Pulau Sikakap. Hasil simulasi menunjukkan pendirian pabrik dan gudang utama sebaiknya didirikan di Pulau Sipora karena menghasilkan total biaya logistik terendah.

Kata kunci: penentuan lokasi, kopra, mentawai, simulasi, biaya logistik

\section{PENDAHULUAN}

Kabupaten Kepulauan Mentawai merupakan salah satu kabupaten di Provinsi Sumatera Barat yang dengan kondisi geografi memiliki banyak gugusan pulau-pulau kecil dengan 3 (tiga) pulau utama yaitu Pulau Siberut, Pulau Sipora dan Pulau Pagai (Gambar 1). Kabupaten Kepulauan Mentawai memiliki jumlah penduduk tercatat sebanyak 81.840 jiwa (BPS, 2014) dengan tingkat kepadatan penduduk Kabupaten Kepulauan Mentawai tahun 2014 rata-rata 14 orang per km²

Laju pertumbuhan ekonomi Kabupaten Kepulauan Mentawai mencapai 5,48\% pada tahun 2014 namun laju pertumbuhan ekonomi tersebut masih berada dibawah rata-rata laju pertumbuhan ekonomi Provinsi Sumatera Barat. Selain itu 
Kabupaten Kepulauan Mentawai menempati rangking tertinggi dari 19 Kabupaten dan Kota di Provinsi di Sumatera Barat, dimana $80 \%$ dari penduduk Kabupaten Kepulauan Mentawai masih hidup dalam kemiskinan (Erwin, 2015). Oleh sebab itu Kabupaten Mentawai sangat membutuhkan pentingnya pembangunan dan pengembangan wilayah di berbagai sektor kehidupan. Pengembangan wilayah dapat dilaksanakan melalui optimasi pemanfaatan sumber daya yang dimiliki secara harmonis, serasi, terpadu, melalui pendekatan yang bersifat komperehensif mencakup aspek fisik, ekonomi, sosial, budaya dan lingkungan hidup untuk pembangunan berkelanjutan (Djakapermana, 2010).

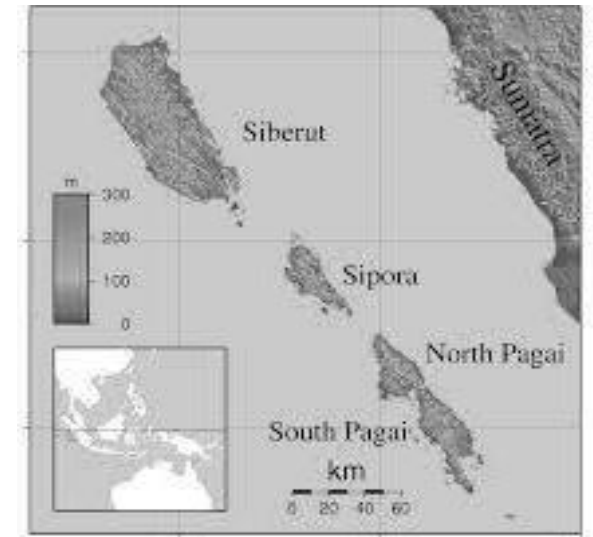

Gambar 1. Kabupaten Kepulauan Mentawai

Salah satu pengembangan yang potensial untuk dilakukan adalah pengembangan sektor pengelolaan hasil bumi dengan komoditas unggulan. Sektor pengelolaan hasil bumi merupakan salah satu sektor yang menjadi perhatian pemerintah dan masyarakat setempat karena telah memberikan kontribusi yang cukup besar bagi perekonomian masyarakat setempat dan juga merupakan salah satu sumber pendapatan pemerintah daerah Mentawai. Salah satu hasil bumi tersebut adalah kopra.

Kopra adalah buah kelapa yang sudah dikeringkan dengan sinar matahari ataupun panas buatan (Palungkun, 2006). Data menunjukkan bahwa luas tanaman kelapa di Kabupaten Kepulauan Mentawai mencapai 7.891 ha dengan produksi kelapa di Kepulauan Mentawai mencapai 7.480 ton pada tahun 2014. Pada umumnya petani kopra yang ada di Mentawai melakukan pengeringan kopra di lingkungan rumah masing-masing dan selanjutnya dijual ke pedagang pengumpul. Pedagang pengumpul menjual kopra kepada pedagang pengumpul yang lebih besar dan kemudian mereka menjual kopra ke luar Kepulauan Mentawai melalui Kota Padang. Kopra diolah lebih lanjut oleh industri berbasis kopra yang terdapat di Padang, Pariaman, Jambi hingga Sumatera Utara. Permasalahan yang dihadapi oleh masyakat setempat pada saat ini adalah sulitnya mencari tempat untuk mengumpulkan kopra pada satu lokasi untuk dikirim ke luar Mentawai. Pihak pengumpul yang ada saat inipun cenderung lebih memiliki posisi tawar yang tinggi sehingga seringkali merugikan petani. Disamping hal itu, kegiatan petani yang hanya melakukan proses pengeringan kelapa hingga menjadi kopra merupakan proses dengan nilai tambah yang sangat kecil. Padahal di sisi lain kopra dapat diolah sehingga menghasilkan berbagai diversifikasi produk. Telah diketahui bahwa kelapa dapat diolah menjadi makanan, minuman, pakaian dan tempat tinggal, juga sebagai sumber pendapatan dari produk-produk olahannya seperti minyak kelapa. Minyak kelapa adalah salah satu sumber minyak nabati yang juga menjadi bahan baku penting dalam industri makanan dan non makananseperti sabun, kimia dan kosmetika (Damanik, 2007). Dari uraian diatas maka terlihat beberapa pemasalahan yanga da dalam pengelolaan komoditas kopra di Kabupaten Kepulauan Mentawai antara lain:

1. Dari aspek resiko rantai pasok kopra, petani kopra menanggung resiko yang besar jika di lihat dari aspek harga dan adanya jaminan permintaan. Sulitnya mendapatkan pengumpul yang selalu siap menampung kopra dan rendahnya posisi tawar petani dalam menetapkan harga merupakan kondisi yang sangat tidak menguntungkan bagi masyarakat petani.

2. Proses pemanenan dan pengeringan kelapa hingga menjadi kopra untuk selanjutnya dijual merupakan proses yang memiliki nilai tambah yang sangat rendah. Kopra selanjutnya akan diolah menjadi berbagai produk diversifikasi produk turunan oleh perusahaan yang berada di luar Kabupaten Kepulauan Mentawai. Hal inijuga menyebabkan keuntungan akan peningkatan nilai tambah tidak sempat dinikmati oleh masyarakat Mentawai penghasil kopra itu sendiri.

Salah satu strategi untuk mengatasi beberapa permasalahan di atas adalah dengan ide dasar pembentukan unit usaha agroindustri yang dapat dikelola oleh pemerintah (BUMD) ataupun swadaya masyarakat. Dengan adanya unit usaha produksi produk-produk turunan diversifikasi kopra pendapatan akan meningkat 5-10 kali lipat dibandingkan dengan bila hanya menjual kopra (Allorerung et al., 2005). Pada prinsipnya unit usaha agroindustri ini diharapkan mampu menjawab atau meminimalisir permasalahan yang telah diuraikan di atas. Unit usaha usulan yang akan dirancang terdiri dari gudang kopra untuk menampung kopra langsung dari petanidan pendirian pabrik produk olahan kopra seperti minyak kelapa (Ekawati dan Nesti, 2016).

Dalam mendirikan suatu usaha seperti agroindustri, penentuan lokasi merupakan salah satu keputusan yang sangat penting dan harus dibuat 
dengan hati-hati (Indarti, 2004). Pemilihan lokasi suatu unit usaha akan mempengaruhi resiko dan keuntungan secara keseluruhan mengingat lokasi sangat mempengaruhi biaya tetap maupun biaya variabel, baik dalam jangka menengah maupun jangka panjang. Sebagai contoh, biaya transportasi saja bisa mencapai $25 \%$ dari harga jual produk (Henzer dan Render, 2006). Menurut Herjanto (2007), pendirian suatu badan usaha perlu memperhatikan faktor letak pasar, letak sumber bahan baku dan ketersediaan tenaga kerja. Penentuan lokasi agroindustri kopra pada penelitian ini lebih memperhatikan pada aspek letak sumber bahan baku dimana lokasi yang ideal adalah lokasi yang menghasilkan biaya serendah mungkin. Melihat kondisi sumber bahan baku.

Mentawai yang kompleks dimana kopra tersebar di berbagai pulau dan memiliki aliran rantai yang cukup panjang sebagimana telah dijabarkan sebelumnya maka penelitian ini bertujuan untuk menentukan lokasi agroindustri dengan yang menhasilkan biaya logistik terendah pendekatan sistem dinamik. Biaya logiatik yang dibahas terdiri dari biaya pengiriman kopra dari petani hingga gudang utama dan biaya simpan kopra di gudang antara maupun gudang utama. Alasan penggunaan sistem dinamik adalah terdapat nilai persediaan kopra sangat tergantung variabel waktu yang membentuk suatu loop yang dipengaruhi oleh jumlah kopra yang masuk atau datang dan jumlah kopra yang dikirim dari suatu tempat penyimpanan.

Penelitian dengan pendekatan sistem memiliki 4 (empat) keuntungan (Barlas, 1996) yaitu (i) memungkinkan melakukan penelitian yang bersifat lintas sektoral dengan ruang lingkup yang luas, (ii) dapat melakukan eksperimentasi terhadap sistem tanpa mengganggu (memberikan perlakuan) tertentu terhadap sistem, (iii) mampu menentukan tujuan aktivitas pengelolaan dan perbaikan terhadap sistem yang diteliti, dan (iv) dapat dipakai untuk menduga (meramal) perilaku dan keadaan sistem pada masa yang akan datang. Sementara itu, sistem dinamik akan menjabarkan suatu hubungan sebab akibat untuk mendapatkan pemahaman terhadap suatu sistem (Asyiawati, 2002).

Model sistem dinamik dapat memberikan perkiraan yang lebih handal daripada model statistik, serta menyediakan cara untuk memahami penyebab prilaku sistem dan penentuan faktor-faktor yang meramalkan prilaku secara signifikan dan sensitif (Lyneis, 2000). Selain itu sistem dinamis dapat mengestimasi kinerja sistem pada kondisi tertentu dan memberikan alternatif desain terbaik sesuai dengan spesifikasi yang diinginkan. Dengan menggunakan sistem dinamis, didapatkan sebuah model dari sistem yang kompleks. Model ini akan digunakan sebagai acuan untuk meningkatkan kinerja perusahaan atau suatu bisnis dalam jangka panjang (Daalen dan Thissen, 2001).

Beberapa penelitian terdahulu ini cukup untuk mendasari penelitian yang berkaitan dengan pembangunan agroindustri kelapa maupun kopra. Wardanu dan Anhar (2014) melakukan penelitian untuk merumuskan strategi pengembangan agroindustri kelapa di Ketapang dimana salah satu strategi yang diusulkan adalah membangun industri pengolahan kelapa, peningkatan infrastruktur dan dengan diversifikasi produk olahan kelapa. Kustanto (1999) melakukan penelitian untuk membantu pengambilan keputusan dalam perencanaan pengembangan agroindustri komoditas unggulan pada kawasan andalan yang merupakan studi kasus di Kabupaten Ciamis dengan menghasilkan program Agrodev. Rukmayadi (2002) melakukan penelitian yang menghasilkan model SPK untuk pemilihan daerah potensial, pemilihan produk prospektif, analisa kelayakan finansial dan Fuzzy interpretative structural, serta strategi pengembangan agroindustri kelapa dengan studi kasus di Kabupaten Ciamis.

\section{METODE PENELITIAN}

Penelitian ini dilaksanakan di Kabupaten Kepulauan Mentawai dan wilayah lainnya di Sumatera Barat. Populasi pada penelitian ini adalah sistem aliran rantai pasok kopra dengan sistem logistik kopra sebagi sub sistem yang diamati. Penelitian ini menggunakan pendekatan simulasi sistem dinamik dengan merancang 3 (tiga) skenario lokasi agroindustri yaitu di Pulau Siberut, Pulau Sipora dan Pulau Pagai. Lokasi agroindustri disini meliputi pabrik pengolahan kopra yang ditunjang oleh satu gudang utama. Pasokan untuk gudang utama berasal dari setiap pulau yang memiliki masing-masing satu gudang pengumpul yang disajikan pada Tabel 1 (Ekawati dan Nesti, 2016).

Tabel 1. Lokasi Gudang Setiap Pulau

\begin{tabular}{cll}
\hline \multicolumn{1}{c}{ Pulau Utama } & \multicolumn{1}{c}{ Kecamatan } & \multicolumn{1}{c}{ Gudang setiap pulau } \\
\hline Siberut & Siberut Utara & Siberut Selatan \\
& Siberut Barat & \\
& Siberut Tengah & \\
& Siberut Barat Daya & \\
& Siberut Selatan & Sipora Selatan \\
Sipora & Sipora Utara & \\
& Sipora Selatan & Sikakap \\
Pagai & Pagai Utara & \\
& Sikakap & \\
& Pagai Selatan & \\
\hline
\end{tabular}


Kopra setiap kecamatan akan dikumpulkan terlebih dahulu di gudang setiap pulau menggunakan bentor yang dikelola oleh unit usaha agroindustri. Selanjutnya kopra dari setiap gudang pulau utama diangkut ke gudang utama yang lokasinya berdekatan dengan lokasi pabrik pengolahan kopra dengan menggunakan kapal laut.

Pengumpulan data primer dilakukan dengan teknik wawancara dengan pelaku rantai pasok kopra di Kabupaten Kepulauan Mentawai dan pengumpulan data sekunder dilakukan pada Badan Pusat Statistik, dan kantor dinas terkait. Perangkat lunak simulasi sistem dinamis yang digunakan dalam penelitian ini adalah powersim. Model simulasi yang dirancang dari causal loop diagram yang diterjemahkan dalam rangkaian model simulasi dalam bentuk flow diagram. Tahapan perancangan model simulasi pada penelitian ini sebagai dasar penentuan lokasi gudang dan agroindustri adalah sebagai berikut:

1. Menentukan ukuran kinerja sistem yaitu biaya logistik yang terkecil yang akan dikeluarkan.

2. Menentukan identifikasi variabel dan parameter model yang ditentukan dengan memperhatikan aktivitas-aktivitas di sepanjang rantai pasok kopra mulai dari pemasok (petani) sampai ke Agroindustri.

3. Merancang Causal Loop Diagram untuk melihat keterkaitan setiap variabel dan umpan balik dari variabel dalam sistem rantai pasok kopra. Causal Loop Diagram memiliki polaritas yang akan menunjukkan arah kausalitas bagaimana perubahan setiap variabel dalam feedback loop (Suryani, 2010a).

4. Menentukan level dan flow sebagai bahasa model untuk menginteraksi hubungan antar variabel dan parameter berdasarkan data dalam sistem nyata

5. Melakukan verifikasi dan validasi model simulasi yang telah dibangun

6. Analisis skenario terhadap beberapa alternatif rancangan penentuan lokasi Agroindustri yang dibangun berdasarkan total ongkos logistik yang dikeluarkan meliputi biaya transportasi dan biaya simpan.

\section{HASIL DAN PEMBAHASAN}

Sebagaimana telah djelaskan sebelumnya, pendirian lokasi pabrik agroindustri dilakukan dengan melihat total biaya logistik yang (akan) muncul. Biaya logistik meliputi biaya transportasi (biaya pengangkutan kopra mulai dari petani ke pabrik) dan biaya simpan kopra di gudang setiap pulau, maupun di gudang utama. Lokasi agroindustri adalah lokasi yang menghasilkan total logistik terkecil. Pemodelan untuk penentuan lokasi pabrik dirangkum pada Tabel 2.

Pembuatan model simulasi ini melibatkan beberapa variabel yaitu: variabel independen (exogenous variabel), variabel dependen (endogenous variabel), variabel kebijakan dan variabel keputusan (Hadiguna, 2015). Variabel independen merupakan variabel yang tidak tergantung pada variabel lain, dalam model ini yang merupakan variabel independen adalah produksi kopra, kapasitas angkut bentor, kapasitas angkut kapal, jarak gudang ke pabrik, jarak kebun ke gudang. Variabel dependen merupakan variabel yang nilainya tergantung dari pada variabel independen, yakni biaya transportasi, biaya simpan, perkembangan persediaan kopra di gudang, laju transportasi darat dan laut.

Diagram causal loop pada Gambar 2 menyatakan hubungan sebab akibat dari variabelvariabel yang ada dalam sistem. Dapat dijelaskan bahwa banyaknya tumpukan kopra dikebun dipengaruhi oleh produksi kopra dari petani, jumlah tumpukan kopra di kebun akan semakin besar seiring dengan meningkatnya produksi kopra, sehingga meningkatkan pasokan kopra ke gudang, di sisi lain dengan peningkatan pasokan kopra di gudang akan mengurangi tumpukan kopra di kebun dan meningkatkan biaya simpan.

Pasokan kopra ke gudang juga dipengaruhi oleh kapasitas angkut bentor ke gudang.Jika kapasitas angkut bentor semakin besar maka semakin banyak pula pasokan kopra ke gudang. Selanjutnya kapasitas angkut bentor, jarak tempuh, frekuensi pengangkutan kopra, biaya moda transportasi (darat dan laut) akan mempengaruhi biaya transportasi.

Berdasarkan causal loop diagram, maka dibuatlah flow diagram yang dituangkan menggunakan software Powersim yang melibatkan variabel turunan dan parameter. Nilai variabel dan parameter merupakan hasil pengamatan lapangan yang dilakukan selama tahun 2016 yang disajikan pada Tabel 3. Penelitian ini tidak mempertimbangkan perubahan harga serta menganggap mutu produk yang dihasilkan sudah sesuai dengan standar kualitas yang ditetapkan.

Tabel 2. Elemen pemodelan rantai pasok kopra

\begin{tabular}{ll}
\hline \multicolumn{1}{c}{ Elemen } & \multicolumn{1}{c}{ Keterangan } \\
\hline a. Ukuran Performasi & Total biaya logistic \\
b. Objektive model simulasi & Minimasi biaya logistik pada sistem rantai pasok \\
c. Variabel keputusan & Lokasi pabrik \\
d. Wilayah feasible keputusan & Discrette alternative \{Kecamatan Siberut Selatan, \\
& Kecamatan Sipora Selatan dan kecamatan Sikakap \\
e. Metode pengambilan keputusan & Simulasi dengan pendekatan sistem dinamik \\
\hline
\end{tabular}




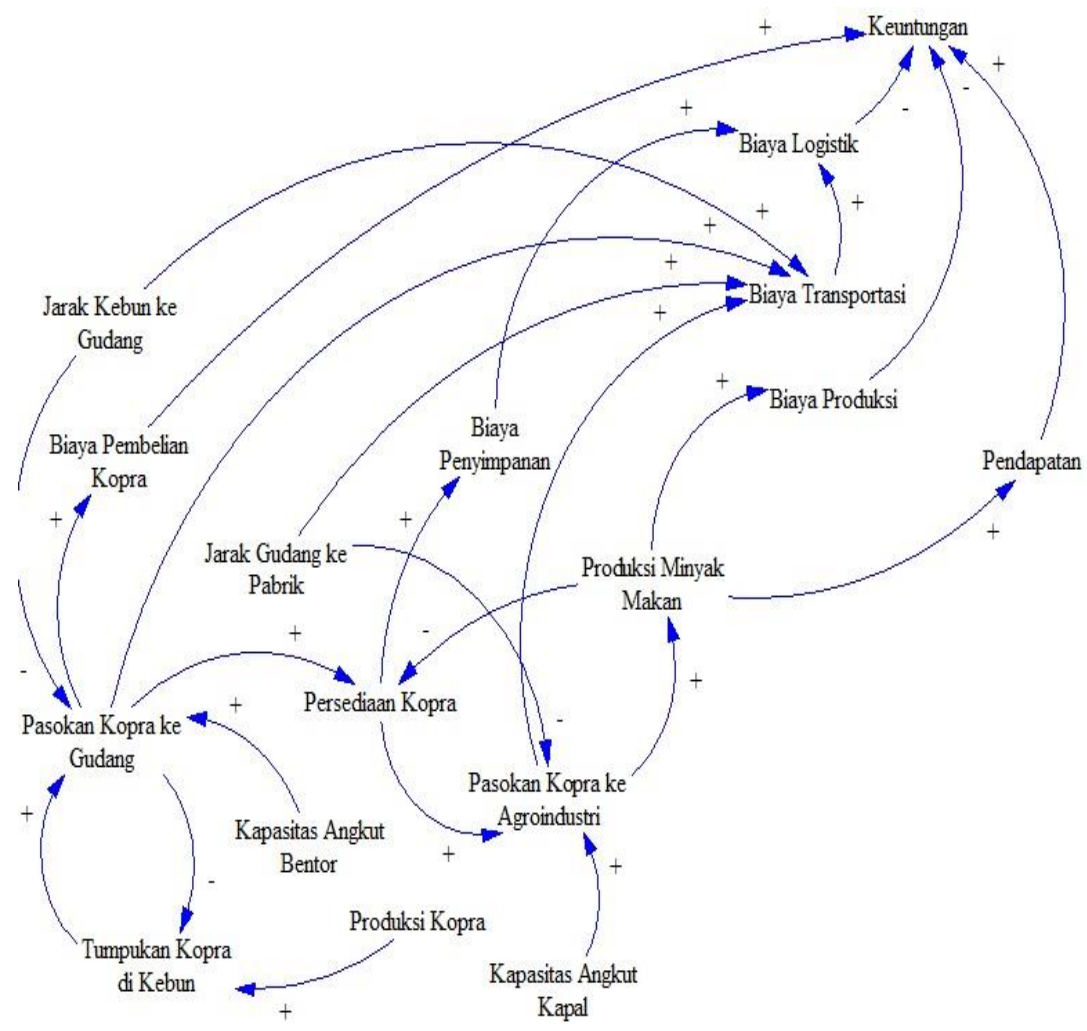

Gambar 2. Causal loop diagram rantai pasok agroindustri kopra mentawai

Tabel 3. Nilai variabel dan parameter pemodelan rantai pasok

\begin{tabular}{|c|c|c|}
\hline Variabel & Nilai dan satuan & Keterangan \\
\hline Produksi kopra & $\begin{array}{l}\text { Data produksi per } \\
\text { kecamatan (ton) }\end{array}$ & $\begin{array}{l}\text { Data produksi (2009-2015) kopra diasumsikan } \\
\text { bersifat probabilistik dengan nilai yang } \\
\text { terdistribusi Normal (mean, standar deviasi). }\end{array}$ \\
\hline Biaya simpan & $\begin{array}{l}10 \% \text { dari nilai kopra } \\
\text { tersimpan }\end{array}$ & $\begin{array}{l}\text { Nilai rata-rata berdasarkan data observasi terhadap } \\
\text { elemen biaya simpan yang dikeluarkan }\end{array}$ \\
\hline Biaya Bentor & Rp 510/km & Biaya bahan bakar + Biaya tenaga kerja angkut \\
\hline Kecepatan bentor & $40 \mathrm{~km} / \mathrm{jam}$ & $\begin{array}{l}\text { Nilai rata-rata berdasarkan data observasi terhadap } \\
\text { kecepatan kendaraan di lapangan }\end{array}$ \\
\hline Kapasitas Bentor & $400 \mathrm{~kg}$ & $\begin{array}{l}\text { Nilai berdasarkan data observasi kapasitas } \\
\text { kendaraan di lapangan }\end{array}$ \\
\hline Harga bahan bakar bentor & $\operatorname{Rp} 7100$ & 1 liter untuk $30 \mathrm{~km}$ perjalanan \\
\hline $\begin{array}{l}\text { Biaya sewa kapal antar } \\
\text { pulau }\end{array}$ & Rp. $6.67 / \mathrm{km} / \mathrm{kg}$ & $\begin{array}{l}\text { Pengolahan sendiri berdasarkan wawancara } \\
\text { pengusaha perkapalan Mentawai }\end{array}$ \\
\hline Jarak antar kecamatan & Sesuai google map $(\mathrm{km})$ & Panjang jalan antar ibukota dua kecamatan \\
\hline Jarak antar pulau & Seduai google map $(\mathrm{km})$ & Jarak antar dua dua gudang di pulau yang berbeda \\
\hline
\end{tabular}

Simulasi menggunakan menggunakan software Powersim Studio Academic 2015. Simulasi dirunning mulai dari tahun 2017 sampai 2027 dengan asumsi sistem agroindustri telah didirikan dan dijalankan mulai tahun 2017. Sesuai dengan tujuan pemodelan yang telah dijelaskan sebelumnya, maka pendirikan pabrik agroindustri dilakukan di tempat yang memberikan total biaya logistik (biaya simpan dan biaya transportasi) terendah. Biaya logistik kumulatif yang dihasilkan proses simulasi disajikan pada Tabel 4.

Berdasarkan Tabel 4. jika pemerintah Kabupaten Kepulauan Mentawai menyetujui untuk membangun agroindustri, maka lokasi Sipora
Selatan dapat dijadi lokasi pendirian agroindustri yaitu berupa gudang utama kopra dan pabrik pengolahan kopra menjadi minyak kelapa. Hasil simulasi menunjukkan bahwa pemilihan lokasi ini memberikan total biaya logistik terendah yaitu sebesar Rp 8.449.791.347 pada tahun 2027. Biaya logistik yang rendah akan mengefisienkan sistem rantai pasok disamping pendirian Badan Usaha Milik Daerah untuk pengolahan kopra ini akan meningkatkan nilai tambah bagi masyarakat Mentawai sendiri mengingat hampir seluruh produksi kopra dijual utuh dan diolah lebih lanjut oleh pihak di luar Mentawai. 
Tabel 4. Biaya logistik kumulatif setiap skenario

\begin{tabular}{crrr}
\hline Tahun & \multicolumn{1}{c}{ Siberut Selatan } & Sipora Selatan & \multicolumn{1}{c}{ Sikakap } \\
\hline 2017 & 0 & 0 & 0 \\
2018 & 892.078 .473 & 741.335 .263 & 546.105 .182 \\
2019 & 1.921 .149 .910 & 1.597 .076 .613 & 1.573 .521 .203 \\
2020 & 2.947 .800 .878 & 2.453 .409 .002 & 3.047 .277 .114 \\
2021 & 3.975 .007 .153 & 3.309 .952 .794 & 4.960 .668 .604 \\
2022 & 5.001 .801 .472 & 4.164 .774 .515 & 7.320 .901 .560 \\
2023 & 6.026 .761 .323 & 5.021 .283 .878 & 10.121 .366 .590 \\
2024 & 7.053 .698 .400 & 5.878 .189 .005 & 13.359 .776 .979 \\
2025 & 8.079 .373 .709 & 6.735 .013 .816 & 17.044 .938 .494 \\
2026 & 9.105 .178 .663 & 7.591 .603 .571 & 21.154 .778 .439 \\
2027 & 10.135 .547 .342 & $\mathbf{8 . 4 4 9 . 7 9 1 . 3 4 7}$ & 25.732 .170 .074 \\
\hline
\end{tabular}

\section{KESIMPULAN DAN SARAN}

\section{Kesimpulan}

Sistem rantai pasok di Kabupaten Kepulauan Mentawai cukup panjang yang dimulai dari petani, pengumpul kecil, pengumpul besar dimana akhirnya pengumpul besar menjual kopra ke luar Mentawai untuk diolah lebih lanjut. Pemerintah setempat sebaiknya mendirikan agroindustri kopra meliputi gudang utama kopra untuk penampung kopra dan pabrik pengolahan kopra menjadi minyak kelapa agar Mentawai mendapatkan nilai tambah yang lebih besar. Penelitian ini mengusulkan lokasi pendirian agroindustri adalah lokasi yang memberikan biaya logistik terendah karena penghematan biaya logistik akan berkontribusi terhadap penghematan ongkos sistem sehingga meningkatkan keuntungan. Penentuan lokasi menggunakan pendekatan sistem dinamik dengan 3 (tiga) skenario lokasi agroindustri yaitu Siberut Selatan, Sipora Selatan dan Sikakap. Hubungan keterkaitan (causal loop) menunjukkan bahwa biaya logistik dipengaruhi oleh biaya simpan dan biaya transportasi. Biaya simpan dipengaruhi oleh jumlah persediaan kopra dan waktu simpan kopra. Biaya transportasi dipengaruhi oleh biaya pengiriman kopra di darat dan biaya pengiriman di laut (antar pulau dalam Kabupaten Kepulauan Mentawai). Simulasi dijalankan menggunakan software Powersim dengan rentang waktu 10 tahun dan hasilnya menunjukkan bahwa pendirian agroindustri di Sipora Selatan memberikan biaya logistik terendah.

\section{UCAPAN TERIMA KASIH}

Terima kasih diucapkan kepada Pusdiklat Kementerian Perindustrian yang telah mendukung terlaksananya penelitian ini.

\section{DAFTAR PUSTAKA}

Allorerung D, Mahmud Z, Wahyudi, Novarianto H, Luntungan HT. 2005. Prospek dan Arah Pengembangan Agribisnis Kelapa. Jakarta:
Badan Penelitian dan Pengembangan Pertanian, Departemen Pertanian.

Asyiawati Y. 2000. Pendekatan sistem dinamik dalam penataan ruang wilayah pesisir. [Tesis]. Bogor: Institut Pertanian Bogor.

Badan Pusat Statistik Kabupaten Kepulauan Mentawai. 2014. Kepulauan Mentawai Dalam Angka: Tuapejat: BPS Kabupaten Kepulauan Mentawai.

Barlas Y. 1996. Multiple test for validation of systems dynamics type of simulation model. European Journal Operational Research. 42(1): 59-87.

Daalen V dan Thissen WAH. 2001. Dynamics Systems Modelling Continuous Models. Faculteit Techniek, Bestuur en Management (TBM): Technische Universiteit Delft.

Damanik S. 2007. Strategi pengembangan agribisnis kelapa (cocos nucifera) untuk meningkatkan pendapatan petani di Kabupaten Indragiri Hilir, Riau. Jurnal Perspektif. 6(2): 94-104.

Djakapermana RD. 2010. Pengembangan Wilayah Melalui Pendekatan Kesisteman. Bogor: IPB Press.

Ekawati I dan Nesti L. 2016. Penentuan lokasi pendirin gudang kopra sebagai penunjang pendirian agroindustri berbasis kopra di Kabupaten Kepulauan Mentawai. Prosiding Seminar Nasional Hasil Riset dan Standarisasi Industri VI. Aceh: 3 November 2016.

Erwin. 2015. Model Pemberdayaan masyarakat mentawai melalui penguatan kelembagaan lokal di pulau siberut empowerment model of the poor in Mentawai through local institutions in Siberut Island. Jurnal Sosio Konsepsia. 4(2): 1-14.

Hadiguna RA. 2015, Dinamika Jaringan Rantai Pasok Biodiesel dari Minyak Goreng Bekas. Padang: Universitas Andalas Press.

Heizer J dan Render B. 2006. Manajemen Produksi. Jakarta: Salemba Empat.

Herjanto E. 2007. Manajemen Operasi. Edisi Ketiga. Jakarta: Grasindo. 
Indarti N. 2004. Business location and success: the case of internet café business in Indonesia. Gadjah Mada International Journal Business. 6(2): 171-192.

Kustanto. 1999. Perencanaan pengembangan agroindustri komoditas unggulan pada kawasan andalan yang merupakan studi kasus di kabupaten ciamis dengan menggunakan program agrodev. [Tesis]. Bogor: Institut Pertanian Bogor.

Lyneis JM. 2000. System dynamics for market forecasting and structural analysis. System Dynamic Review. 16(1): 3-25.

Palungkun R. 2006. Aneka Produk Olahan Kelapa. Jakarta: Penebar Swadaya.

Rukmayadi D. 2002. Desain sistem penunjang keputusan perencanaan strategi pengembangan agroindustri kelapa studi kasus Kabupaten Ciamis Jawa Barat. [Tesis]. Bogor: Institut Pertanian Bogor.
Suryani E, Chou SY, dan Chen CH. 2010. Air passenger demand forecasting and passenger terminal capacity expansion: a system dynamics framework, Expert Systems with Applications. 37 (3): 23242339.

Wardanu AP dan Anhar M. 2014. Strategi pengembangan agroindustri kelapa sebagai upaya percepatan ekonomi masyarakat di Kabupaten Ketapang. Jurnal Teknologi dan Agroindustri. 3 (1): 13-26. 